\title{
Relationship of the productivity of forest den- drocenoses with the geomorphological profile of soils and their influence on the ecology
}

\author{
V.K. Khlyustov ${ }^{1, *}$, V.A. Sedykh ${ }^{1,2}$, V.D. Naumov ${ }^{1}$, A.M. Ganikhin ${ }^{1}$, \\ and N.L. Kamennykh ${ }^{1}$ \\ ${ }^{1}$ Russian State Agrarian University - MSHA named after K. A. Timiryazev», Moscow, Russian Fed- \\ eration \\ ${ }^{2}$ Federal State Research Institute of the Federal Penitentiary Service of the Russian Federation, Mos- \\ cow, Russian Federation
}

\begin{abstract}
It is well known that there is a relationship between the productivity of forest phytocenoses and soil fertility, which is largely determined by the terrain and soil geomorphology. An important element of assessing the productivity of forests is the substantiation of the methodology for modeling the age dynamics of the growth of forest stands, depending on soil and ground conditions. The solution of this methodological problem is possible only if there is data on forest objects, represented by permanent sample plots and data from a detailed soil survey.
\end{abstract}

\section{Introduction}

In our case, the object of the study was the Lesnaya Opytnaya Dacha (Forest experimental site) (FES), which is a scientific station and an educational training ground with an area of 232.3 hectares on the territory of Moscow. In the forest area, long-term periodic (after 10-15 years) observations of the growth, structure and productivity of forest stands are carried out, as well as their impact on the environment is assessed. The organization of the FES territory is associated with the name of the famous scientist-forester Count A.R. Vargas de Bedemar. which in 1863 carried out the first forest inventory [1 ]. The forest area was divided into 14 quarters with a description of plantings in them and the establishment of permanent sample plots. Later, scientists-foresters of the Petrovskaya and Timiryazevskaya academies V.T. Sobichevsky, M.K. Tursky, N.S. Nesterov, V.P. Timofeev, G.R. Eitingen, A.N. Polyakov and others continued to observe naturally forming forest stands and forest cultures of various mixing and density. In total, 156 test plots were laid in the plantings, on which regular observations have been carried out for more than 150 years. The forest growing conditions of FES are represented by meso-hygrophilic (C3) and hygrophilic (C4) complex subors - relatively rich soils. However, the accepted classification only in the first approximation characterizes the soil-typological conditions found in the forest area.

\footnotetext{
* Corresponding author: helenr2003@mail.ru
} 
S.V. Zonn [8 ], B.D. Zaicev [6 ], N.P. Remezov, P.S. Pogrebnyak [13 ], L.O. Karpachevsky [9 ] Yu.P. Demakov et al. [4 ] indicate that it is the soil that is the leading component of the biogeocenosis, which determines its structural organization, dynamics and productivity.

G.N. Vysotsky is a contemporary and student of K.A. Timiryazev and V.V. Dokuchaeva developed the doctrine of forest-vegetation zoning, developed a diagram of natural zones demonstrating the relationship between the distribution of forest vegetation, depending on climatic, soil and hydrological conditions. The scheme proposed by him has not lost its significance so far. He made a significant contribution to the study of the impact of forests on the environment, to the classification of types of water regime of soils and grounds [12].

Later N.V. Dylis, V. N. Sukachev [5 ] for the first time formulated the theory of the horizontal structure of forest biogeocenoses (BGC). Starting with the works of L.O. Karpachevsky $[9,10]$ the idea gradually developed that the soil cover in forest biogeocenoses resembles a honeycomb (parcell) structure. A parcel represents forest areas isolated in space (along a conventional radius), formed by a specific edificator and dominants of the vegetation cover. Within the parcel, along the radius from the edificator, the influx of litter, accumulation of litter, consumption of water and nutrients change.

Yu.P. Demakov, A.V. Isaev [3] indicate that at present, a lot of factual field material has been accumulated, various kinds of measurements for systematization and data processing. This requires only the correct formulation of problems in identifying conformities (relationships), the use of system analysis with elements of mathematical statistics and modeling methods.

In modern economic conditions, large-scale field surveys are very problematic, therefore, the use of field material already accumulated by predecessors, both on soils and on the growth, productivity of forest phytocenoses, should be considered a good basis for successfully solving the problem posed in the study.

V.D. Zelikov [7] it is shown that the granulometric composition of soils and the thickness of the soil profile has an important role in the ontogeny of forest stands. Using statistically reliable data, the author has shown that forest stands with a predominance of pine reach the highest bonitet (I-I ${ }^{\text {a }}$ ) in those cases when they grow on deep sandy loamy-sandy deposits, as well as loamy soils up to $120 \mathrm{~cm}$ thick. D.A. Danilov and V.P. Tsarenko [2], studying the influence of the granulometric composition of soils on the productivity of naturally formed stands of spruce and pine in the conditions of the Northwest region. They noted that on loamy and sandy loamy soils, the pine element of the forest shows greater productivity and better marketable qualities of wood than spruce. The authors conclude that with age in these soil conditions, pine mixed with spruce covers most of the ecological niche, which affects the overall productivity of forest stands.

O.V. Martynenko [11] provides information on the developed regression model of the productivity of pine forest stands of SCHUOLKh of the Moscow region. At the same time, it is indicated that information on bonitet classes, expressed by the average height of stands at 100 years of age, was taken as an independent variable. And as independent variables in the formation of the model, such variables as the level of groundwater, the content of humus in the root-accessible soil layer and the upper boundary of the appearance of signs of gleying in the mineral part of the profile are involved. At the same time, it is noted that bonitet is a dynamic indicator and not sufficiently reliable for long-term forecasting.

The presence of permanent sample plots of FES opens up great opportunities for conducting research that allows one to assess the role of various elements of dendrocenosis of artificial and natural origin on the soil-forming process and the structure of sod-podzolic soils. At the same time, the data of taxation indicators of forest stands on permanent sample plots make it possible to reveal the influence of soil characteristics on the dynamics of productivity of dendrocenosis elements [16]. 
The aim of the study was to develop a methodology for assessing the dynamics of growth by average height and productivity of closed stands located at different levels of geomorphological soil surfaces.

Study objectives:

1.Conduct modeling of age-related changes in the average height of the main forest elements based on data from permanent sample plots.

2.Reveal the relationship between the levels of productivity of forest stands located at different elevations of geomorphological surfaces.

\section{Research methods}

Experimental material is represented by a series of sample plots (Table 1), presented in different parts of the FES geomorphological profile (Fig. 1).

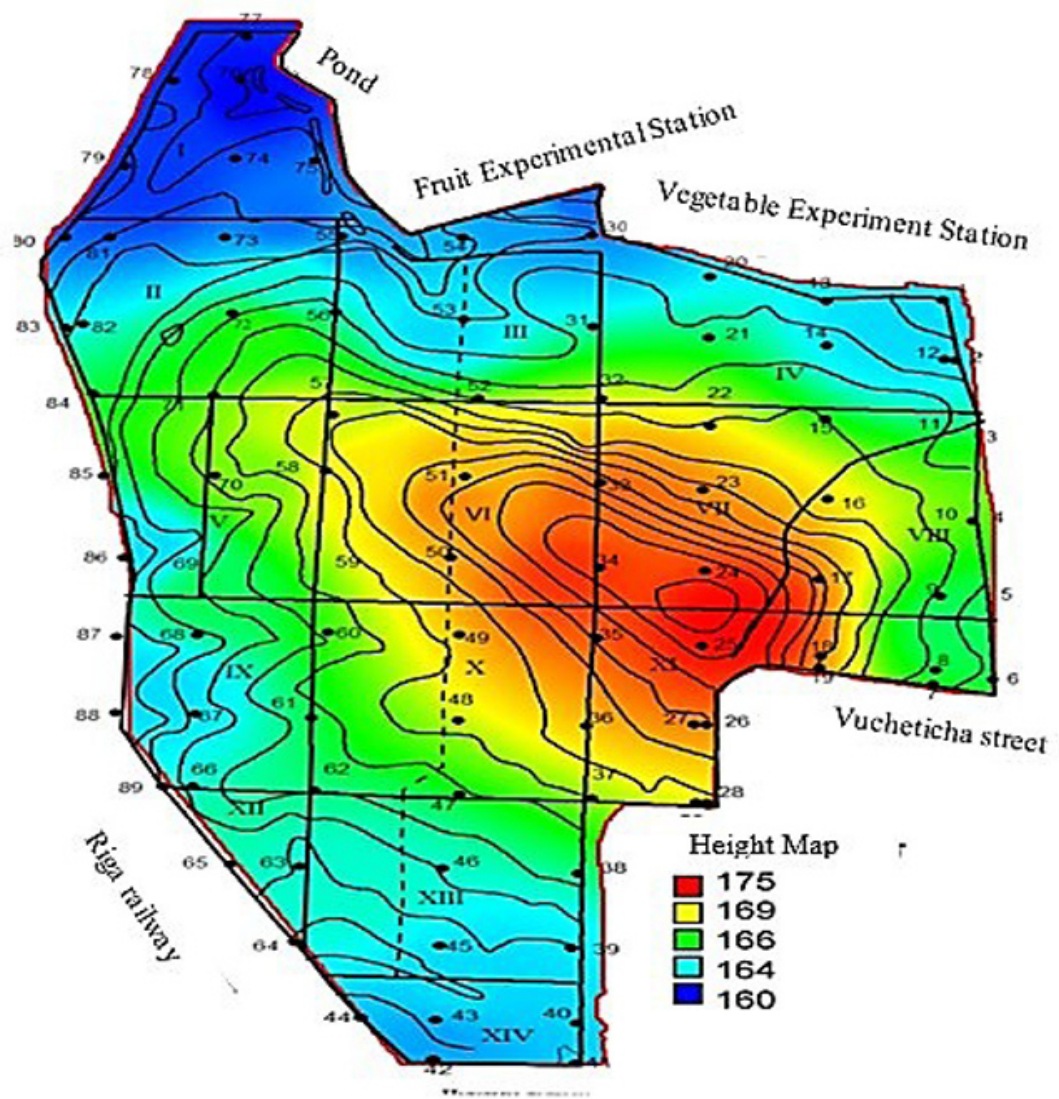

Fig.1. Altitude marks of the FES territory. 
Table 1. Soil and forest inventory characteristics of the sample plots.

\begin{tabular}{|c|c|c|c|c|c|c|}
\hline 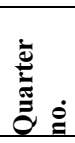 & 产 & $\begin{array}{l}\text { Forest stand } \\
\text { composition }\end{array}$ & Origin & 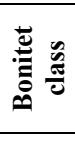 & $\begin{array}{l}\text { Height } \\
\text { mark in } \\
\text { the re- } \\
\text { lief, } m \\
\end{array}$ & $\begin{array}{c}\text { Soil classification } \\
\text { name }\end{array}$ \\
\hline IV & M & 9S1Lp & artificial & 2 & 166,1 & $\begin{array}{l}\text { Sod-podzolic deep- } \\
\text { soddy strongly - super- } \\
\text { deep podzolic light } \\
\text { loamy on moraine me- } \\
\text { dium loam. Pd } \text { 5-3/5 } \\
\text { lsMs }\end{array}$ \\
\hline IV & F & $9 \mathrm{C} 1 \mathrm{E}$ & artificial & 2 & 165,4 & $\begin{array}{l}\text { Sod-podzolic deep- } \\
\text { soddy strongly - super- } \\
\text { deep podzolic light } \\
\text { loamy on moraine } \\
\text { light loam. Pd } \text { 5-3/5 } \\
\text { lsMls }\end{array}$ \\
\hline IV & $\mathrm{L}$ & 9S1Lp & artificial & 2 & 166,9 & $\begin{array}{l}\text { Sod-podzolic medium- } \\
\text { sod strongly-deep pod- } \\
\text { zolic deep-gley light } \\
\text { loamy on sandy loam } \\
\text { moraine deposits. Pd } \\
\text { G11 }{ }_{4-3 / 4} \text { IsMs }\end{array}$ \\
\hline IV & $\mathrm{R}$ & 8S1B1E & artificial & 2 & 168,1 & $\begin{array}{l}\text { Sod-podzolic deep- } \\
\text { soddy strongly - super- } \\
\text { deep podzolic sandy } \\
\text { loam on moraine light } \\
\text { loam. Pd } \text { 5-3/5 }_{\text {sMls }} \\
\end{array}$ \\
\hline IV & Z & 6S2B1Lp1D & artificial & 1 & 165,4 & $\begin{array}{l}\text { Sod-podzolic deep- } \\
\text { soddy shallow-deep- } \\
\text { podzolic deep-gley } \\
\text { light loamy on mo- } \\
\text { raine light loam. PD } \\
\text { Gi1 }{ }_{5-2 / 4} \text { ISMls }\end{array}$ \\
\hline IV & - & 8S2Lp & artificial & 2 & 168,1 & $\begin{array}{l}\text { Sod-podzolic deep- } \\
\text { soddy strongly - super- } \\
\text { deep podzolic sandy } \\
\text { loam on moraine light } \\
\text { loam. Pd } \text { f-3/5 }_{\text {SMls }}\end{array}$ \\
\hline IV & K & 9S1Lp & artificial & 2 & 167,8 & $\begin{array}{l}\text { Sod-podzolic deep- } \\
\text { soddy strongly - super- } \\
\text { deep podzolic light } \\
\text { loamy on moraine me- } \\
\text { dium loam. Pd } \text { 5-3/5 } \\
\text { lsMs }\end{array}$ \\
\hline IV & V & 9S1Lp & artificial & 2 & 165,7 & $\begin{array}{l}\text { Sod-podzolic deep- } \\
\text { soddy strongly - super- } \\
\text { deep podzolic deep- } \\
\text { gley light loamy on } \\
\text { moraine medium } \\
{\text { loam. Pd }{ }_{6-3 / 5}}_{\text {lsMs }}\end{array}$ \\
\hline
\end{tabular}


Table 1. Continued.

\begin{tabular}{|c|c|c|c|c|c|c|}
\hline 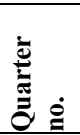 & 咅 흘 & $\begin{array}{l}\text { Forest stand } \\
\text { composition }\end{array}$ & Origin & 绨 & $\begin{array}{c}\text { Height } \\
\text { mark in } \\
\text { the re- } \\
\text { lief, } m\end{array}$ & $\begin{array}{c}\text { Soil classification } \\
\text { name }\end{array}$ \\
\hline IV & $\mathrm{S}$ & $7 \mathrm{C} 2 \mathrm{E} 1 \mathrm{~B}$ & artificial & 2 & 166,8 & $\begin{array}{l}\text { Sod-podzolic medium- } \\
\text { sod strongly-deep pod- } \\
\text { zolic deep-gley light } \\
\text { loamy on sandy loam } \\
\text { moraine deposits. Pd } \\
\text { G11 } \\
4-3 / 4 \\
\text { IsMs }\end{array}$ \\
\hline IV & U & $9 \mathrm{C} 1 \mathrm{E}$ & artificial & 2 & 165,8 & $\begin{array}{l}\text { Sod-podzolic deep- } \\
\text { soddy strongly - super- } \\
\text { deep podzolic light } \\
\text { loamy on moraine me- } \\
\text { dium loam } \text { Pd }_{5-3 / 5} \\
\text { lsMs }\end{array}$ \\
\hline IV & $\mathrm{O}$ & $10 \mathrm{C}$ & artificial & 2 & 165,4 & $\begin{array}{l}\text { Sod-podzolic deep- } \\
\text { soddy strongly - super- } \\
\text { deep podzolic light } \\
\text { loamy on moraine } \\
\text { light loam. Pd } \text { 5-3/5 } \\
\text { lsMls }\end{array}$ \\
\hline IV & U & 5S5Lp & artificial & 2 & 165,7 & $\begin{array}{l}\text { Sod-podzolic deep- } \\
\text { soddy strongly-deep } \\
\text { podzolic medium } \\
\text { loamy on moraine } \\
\text { light loam. } \text { P }_{\text {D5-3/4 }} \\
\text { sMls }\end{array}$ \\
\hline VI & $\mathrm{C}$ & 5O5Lp & artificial & 1 & 170,7 & $\begin{array}{l}\text { Sod-podzolic deep- } \\
\text { soddy strongly - super- } \\
\text { deep podzolic light } \\
\text { loamy on moraine } \\
\text { sand. P } \text { D5-3/5 }_{\text {hpMP }}\end{array}$ \\
\hline V & D & 5S5Lp & artificial & 2 & 168,1 & $\begin{array}{l}\text { Sod-podzolic deep- } \\
\text { soddy strongly - super- } \\
\text { deep podzolic profile - } \\
\text { gleyic light loamy on } \\
\text { moraine sand. PD G13 } \\
\text { 3/5 hpMP }\end{array}$ \\
\hline V & V & 6Lp4S & artificial & 1 & 168,6 & $\begin{array}{l}\text { Sod-podzolic deep- } \\
\text { soddy strongly - super- } \\
\text { deep podzolic profile - } \\
\text { gleyic light loamy on } \\
\text { moraine sand. PD }{ }^{\text {G13 }} \\
\text { 3-5 hpMP }\end{array}$ \\
\hline VII & $P$ & $10 \mathrm{~L}$ & artificial & $1 \mathrm{~b}$ & 172,8 & $\begin{array}{l}\text { Sod-podzolic deep- } \\
\text { soddy medium-deep } \\
\text { podzolic light loamy } \\
\text { on moraine light loam. } \\
\text { P }_{\text {D5-2/4 hpMls }}\end{array}$ \\
\hline
\end{tabular}


Table 1. Continued.

\begin{tabular}{|c|c|c|c|c|c|c|}
\hline 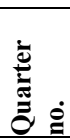 & 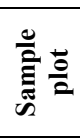 & $\begin{array}{l}\text { Forest stand } \\
\text { composition }\end{array}$ & Origin & 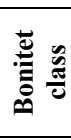 & $\begin{array}{c}\text { Height } \\
\text { mark in } \\
\text { the re- } \\
\text { lief, } m\end{array}$ & $\begin{array}{c}\text { Soil classification } \\
\text { name }\end{array}$ \\
\hline VII & $\mathrm{R}$ & $10 \mathrm{~L}$ & artificial & V & 173,4 & $\begin{array}{l}\text { Sod-podzolic deep- } \\
\text { soddy weakly-deep } \\
\text { podzolic light loamy } \\
\text { on moraine light loam. } \\
\text { P }_{\text {D5-1/4 hpMls }}\end{array}$ \\
\hline VII & $\mathrm{K}$ & $8 \mathrm{C} 2 \mathrm{Kl}$ & natural & $1 \mathrm{~b}$ & 172,8 & $\begin{array}{l}\text { Sod-podzolic medium- } \\
\text { soddy medium-deep } \\
\text { podzolic profile-gley } \\
\text { medium loamy, on a } \\
\text { sandy loam moraine. P } \\
{ }_{\text {Di3 }}{ }_{\text {5-2/4 }} \text { IsMsp }\end{array}$ \\
\hline VII & S & 8L2Lp & artificial & $1 \mathrm{a}$ & 172,8 & $\begin{array}{l}\text { Sod-podzolic medium } \\
\text { sod medium - deep } \\
\text { podzolic medium } \\
\text { loamy on moraine me- } \\
\text { dium loam. } \text { P }_{\text {D4-2/4 }} \\
\text { lsMls }\end{array}$ \\
\hline VII & $\mathrm{E}$ & $6 \mathrm{~L} 2 \mathrm{Kl}$ & artificial & 1 & 173,9 & $\begin{array}{l}\text { Sod-podzolic deep- } \\
\text { soddy medium-deep } \\
\text { podzolic deep-gley } \\
\text { light loamy, on mo- } \\
\text { raine light loam. PD } \\
{ }_{\text {G11 }}{ }_{5-2 / 4} \text { IsMls }\end{array}$ \\
\hline XI & B2 & $6 \mathrm{Lp} 4 \mathrm{~S}$ & artificial & 2 & 175 & $\begin{array}{l}\text { Sod-podzolic medium- } \\
\text { sod medium-deep pod- } \\
\text { zolic sandy loam soil } \\
\text { on moraine sand. } \mathbf{P}_{\text {D4- }} \\
2 / 4 \text { SpMP }\end{array}$ \\
\hline XI & M & 5Lp4D1B & natural & 1 & 169,6 & $\begin{array}{l}\text { Sod-podzolic deep-sod } \\
\text { medium-deep podzolic } \\
\text { deep-gley light loamy } \\
\text { on moraine sand. P } \\
\text { GI1 }_{\mathbf{6 - 2} / \mathbf{4}} \mathbf{I S M s}\end{array}$ \\
\hline VIII & $\mathrm{N}$ & 8D2Lp & natural & 2 & 168,5 & $\begin{array}{l}\text { Sod-podzolic deep- } \\
\text { soddy medium-deep } \\
\text { podzolic light loamy } \\
\text { on moraine sandy } \\
\text { loam. } \text { P }_{\text {D5-2/4 }} \text { lsMsp }\end{array}$ \\
\hline VIII & $\mathrm{O}$ & $10 \mathrm{D}$ & natural & 1 & 165,4 & $\begin{array}{l}\text { Sod-podzolic deep- } \\
\text { soddy medium-super- } \\
\text { deep podzolic profile - } \\
\text { gleyic light loamy on } \\
\text { moraine sand. PD }{ }^{\text {Gl3 }} \\
{ }_{2 / 5} \text { IsMP }\end{array}$ \\
\hline
\end{tabular}


Table 1. Contunued.

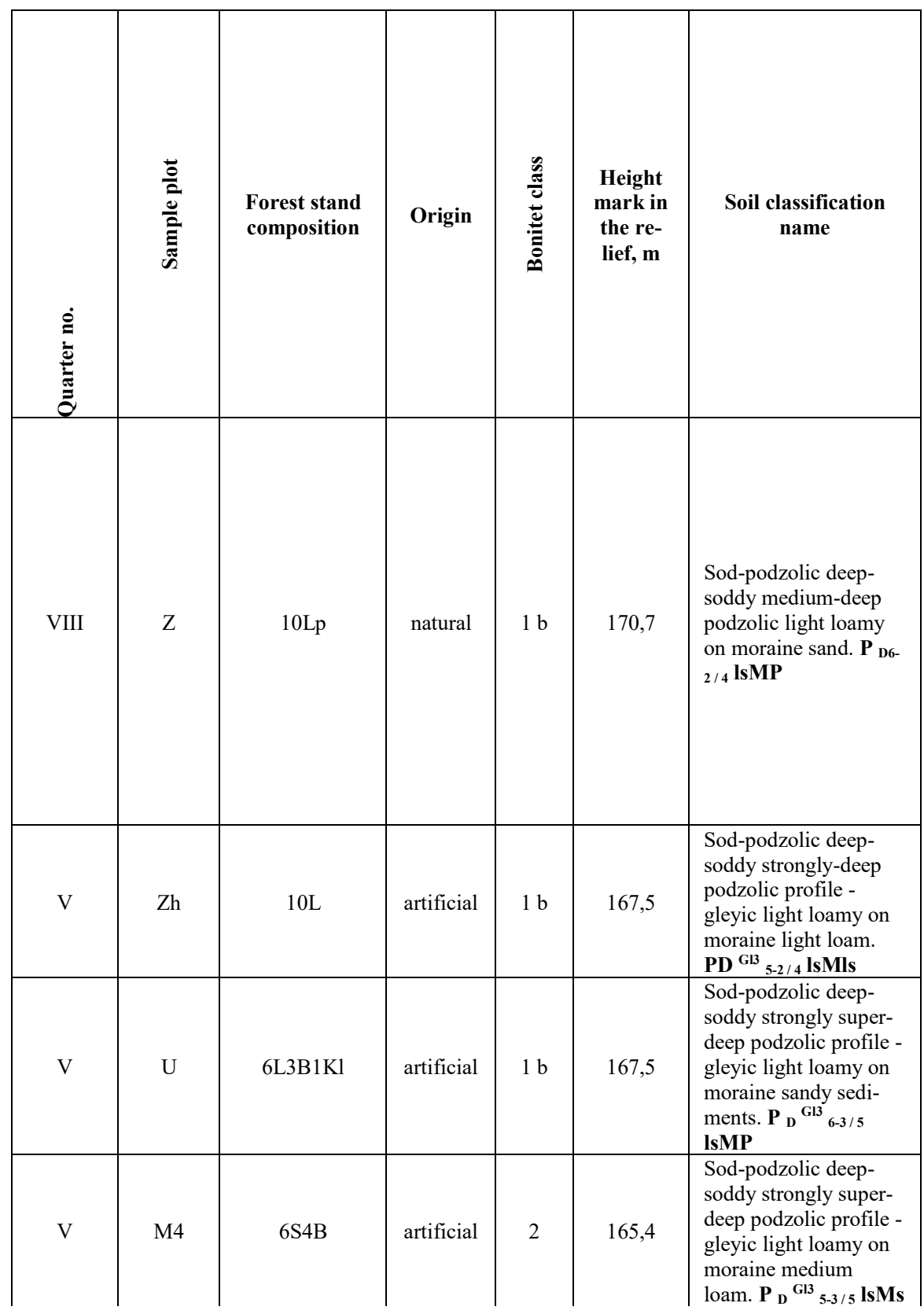


Table 1. Continued.

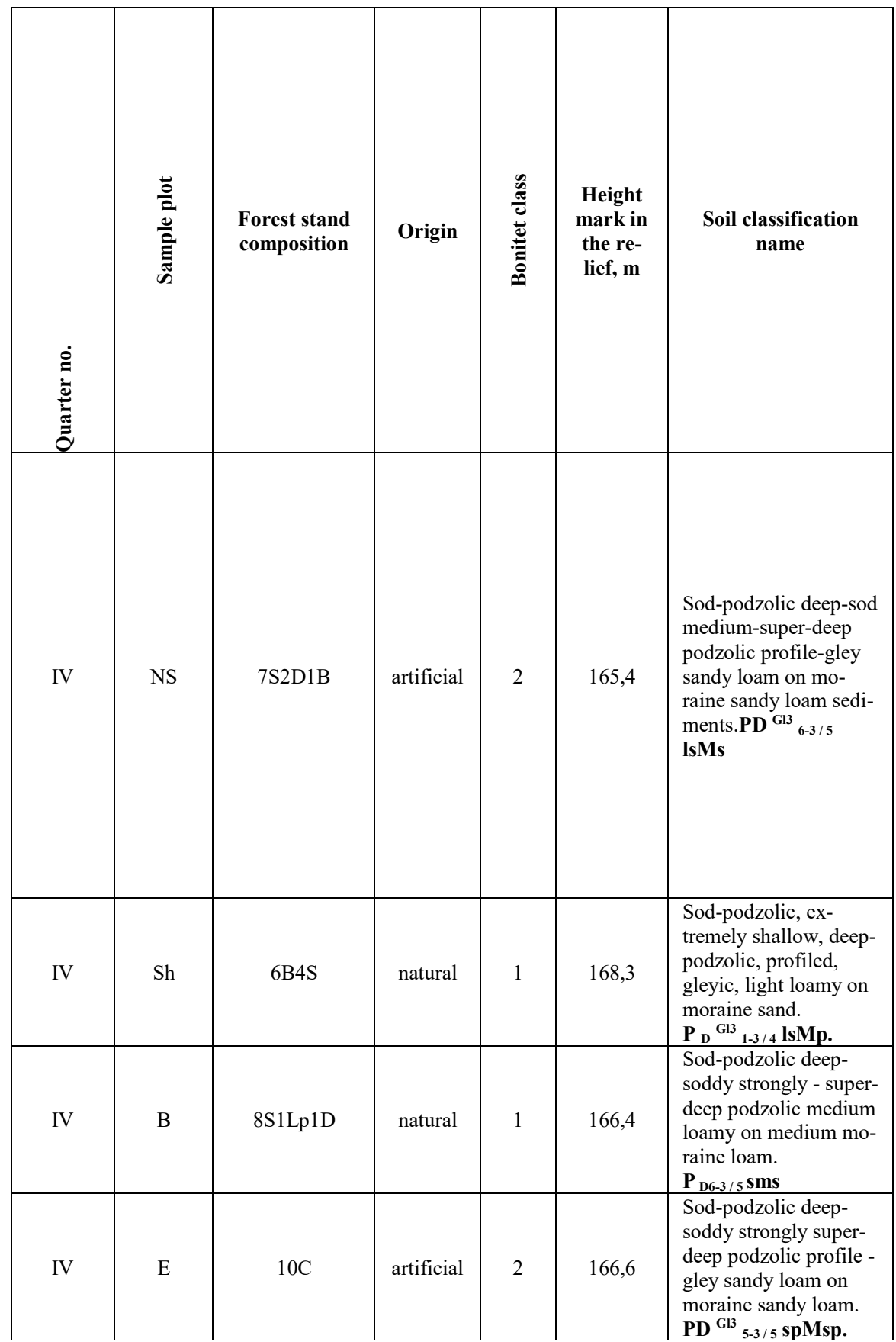


Table 1. Continued.

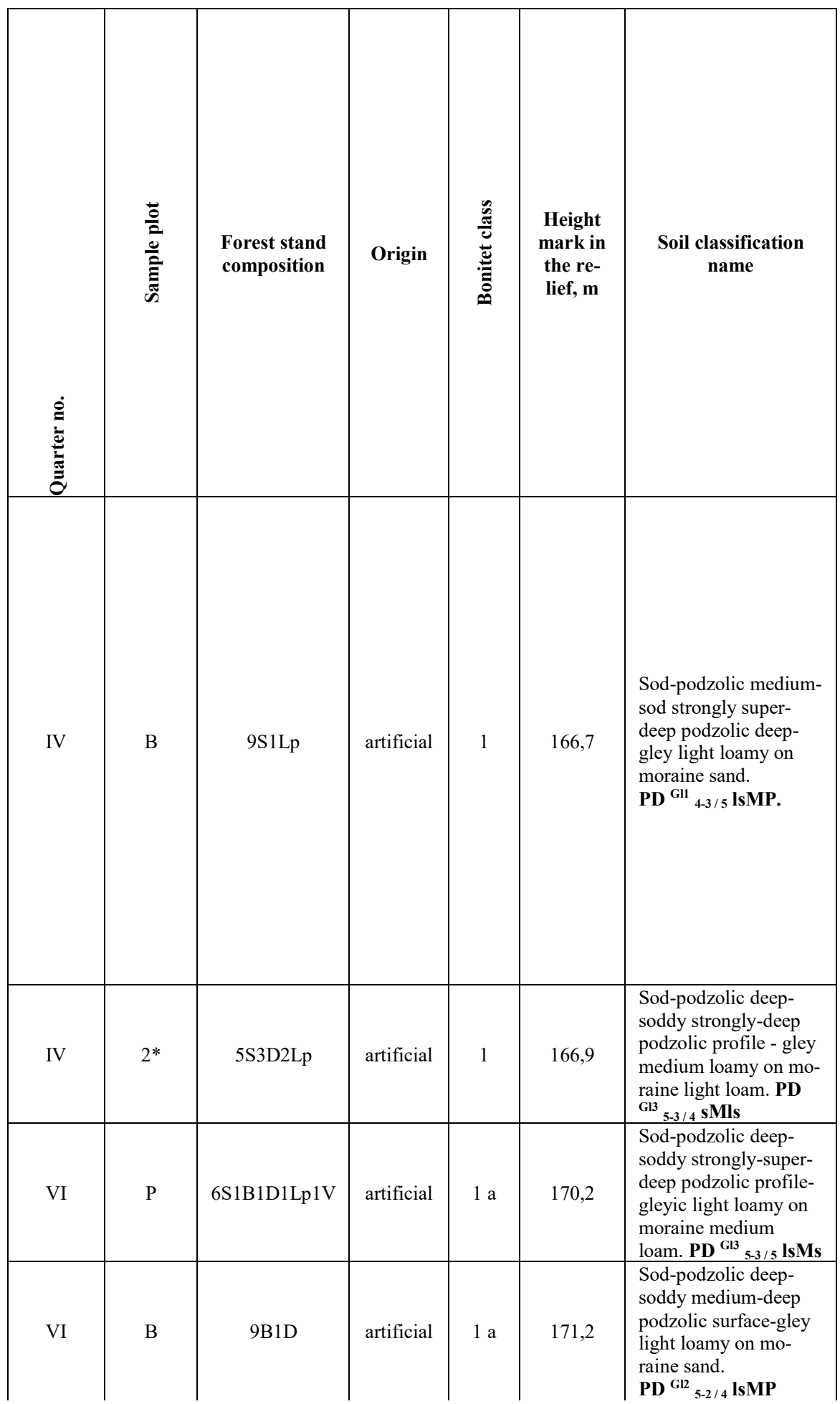


Table 1. Continued.

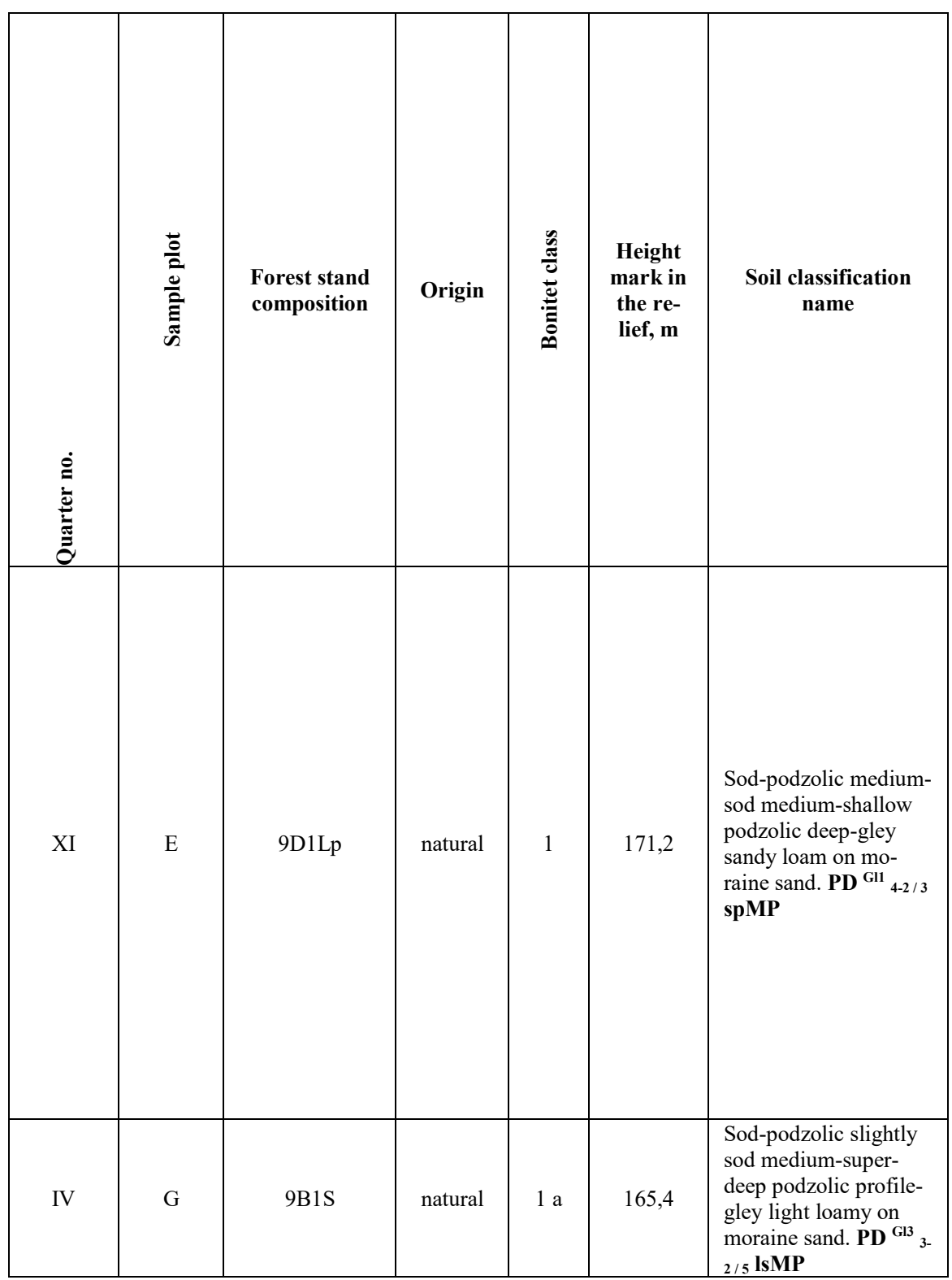

Judging by the share of tree species in the composition of forest stands, they can be conditionally attributed to pine (57\%), larch (14\%), linden (14\%), oak (8\%) and birch (8\%).

It should be noted that the generally accepted tool in forestry and forest inventory for assessing the productivity of plantations is the boniteration scales of Professor M.M. Orlov separately for seed and coppice stands, as well as the improved VNIILM quality class scale, which takes into account the growth energy of stands at average height for forest-forming species of slow, moderate and fast growth. Bonitet is mainly a classification characteristic of forest stands by productivity (stock) at the time of taxation. He only states the level of 
productivity, not linking it with the geomorphology and forest vegetation properties of soils $[17,18]$.

By the decision of the silvicultural part of the work, it is envisaged to link the geomorphological surfaces of the Lesnaya Opytnaya Dacha with the productivity of forest phytocenoses. It is generally accepted to assess the productivity levels of forest stands either on a bonitet or on a forest typological basis according to the relationship between the average height of the forest stands with age [14]. Observing this condition for each of 38 permanent sample plots, we simulated the age-related change in the average height of the stand according to the growth function of Korsun-Bakman:

$$
\mathrm{H}=\exp \left(k_{0}+k_{1} \ln A+k_{2} \ln ^{2} A\right)
$$

In all cases, the smoothing of the empirical data of the sample plots is characterized by a very high closeness of the relationship, close to the functional one, with a coefficient of determination from 0.995 to 0.999 .

Further, for each sample plot, using the indicated regression equations, the average height at 40,70 and 100 years of age was determined. The obtained values of the average heights were included in the calculation of the numerical regression coefficients. Along with this, a matrix of binary variables was compiled, encoding conventionally given decades with a gradation of 30 years (Table 2) in accordance with the guidelines set out in the monograph [15 ].

Table 2. Coding of the levels of the average height of stands for three age groups with block fictitious variables $\left(\mathrm{X}_{\mathrm{i}}\right)$.

\begin{tabular}{|c|c|c|}
\hline \multirow{2}{*}{$\begin{array}{c}\text { Average height at age, } \\
\text { years }\end{array}$} & \multicolumn{2}{|c|}{ Block fictious variables } \\
\cline { 2 - 3 } & $\boldsymbol{X}_{\boldsymbol{1}}$ & $\boldsymbol{X}_{\mathbf{2}}$ \\
\hline 40 & 0 & 0 \\
\hline 70 & 1 & 0 \\
\hline 100 & 0 & 1 \\
\hline
\end{tabular}

Multiple regression analysis made it possible to obtain an equation for the relationship between the average height of forest stands and the height of objects above sea level in accordance with the coordinates of the geolocation of test plots of the type:

$$
\begin{aligned}
& \mathrm{H}_{s r}=\exp \left(-25,8675+5,5899 \ln \mathrm{H}_{U M}+0,3704 \mathrm{X}_{1}+0,5292 \mathrm{X}_{2}\right) \\
& R^{2}=0,771 ; E S= \pm 13,1 \% ; t=|3,3 ; 3,6 ; 7,2 ; 9,8|>t_{05}=1,96 ; F=39,27 \\
& \text { at } P<0.05 ; \Delta=0.81 \% ; O_{\sigma}= \pm 12.7 \% ; \lim \mathrm{H}_{\mathrm{UM}}=160-175 \mathrm{~m}
\end{aligned}
$$

where:

$\mathrm{H}_{\mathrm{cp}}$ - average height of the stand, $\mathrm{m}$;

$\mathrm{H}_{\mathrm{yM}}$ - height above sea level, $\mathrm{m}$;

$\mathrm{X}_{1}, \mathrm{X}_{2}$ - block fictitious variables;

$\mathrm{R}^{2}$ - coefficient of determination;

ES is the standard error of the regression equation;

$\mathrm{t}$ - Student's criterion;

$F$ - Fisher's criterion;

$\mathrm{P}$ - the significance of the differences according to the F criterion;

$\Delta$ - systematic error of the equation, $\%$; 
About $_{\sigma}$ - random error of the equation, $\%$.

The presented parameters of the model (1) indicate the presence of a close relationship between the average height of the forest stands with the independent variables included in the equation, covering $77 \%$ of the variance of the dependent variable. The statistical significance of the parameters of the equation, the absence of a systematic error $(\Delta=0.81 \%)$ and the presence of a random error not exceeding $\pm 13 \%$ indicate a sufficiently high accuracy of the model, which takes into account only one physical indicator - the height above sea level.

The degree of correspondence of the theoretical values of heights to the actual ones is clearly shown in Figure 2. The location of the theoretical values of the height along the diagonal of the square of the adequacy assessment confirms the conclusion made.

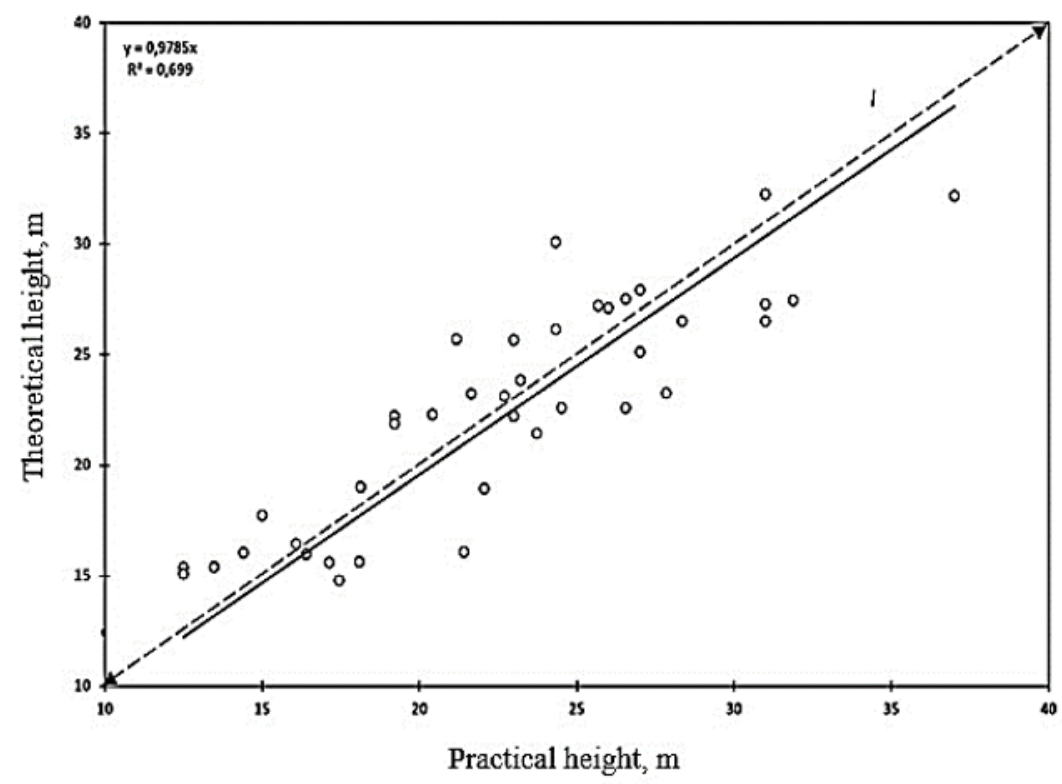

Fig. 2. Visualization of the correspondence of theoretically obtained values of average heights according to model (I) to actual data.

Further, to represent the conformities of change in the average height of forest stands (A, years), taking into account the elevation marks of the geomorphological profile $\left(H_{\mathrm{yM}}\right)$ model (1) was transformed into a functional regression equation of the form:

$$
\mathrm{H}=\exp \left(-32,01974+2,54107 \ln \mathrm{A}-0,23674 \ln ^{2} A+5,58992 \ln H_{U \mathrm{M}}\right)
$$

$$
\mathrm{R}^{2}=1,0 ; \mathrm{t}>\mathrm{t}_{05}=1,96
$$

The age-related change in the average heights of forest stands growing at different heights of the geomorphological profile of the FES is shown in Figure 3

A graphical interpretation of the new model is shown in Figure 4. The theoretically obtained tabular data, as well as the three-dimensional graph of changes in the average heights of forest stands in terms of age and height above sea level, clearly indicate a high degree of mutual influence of the variables included in the model. 


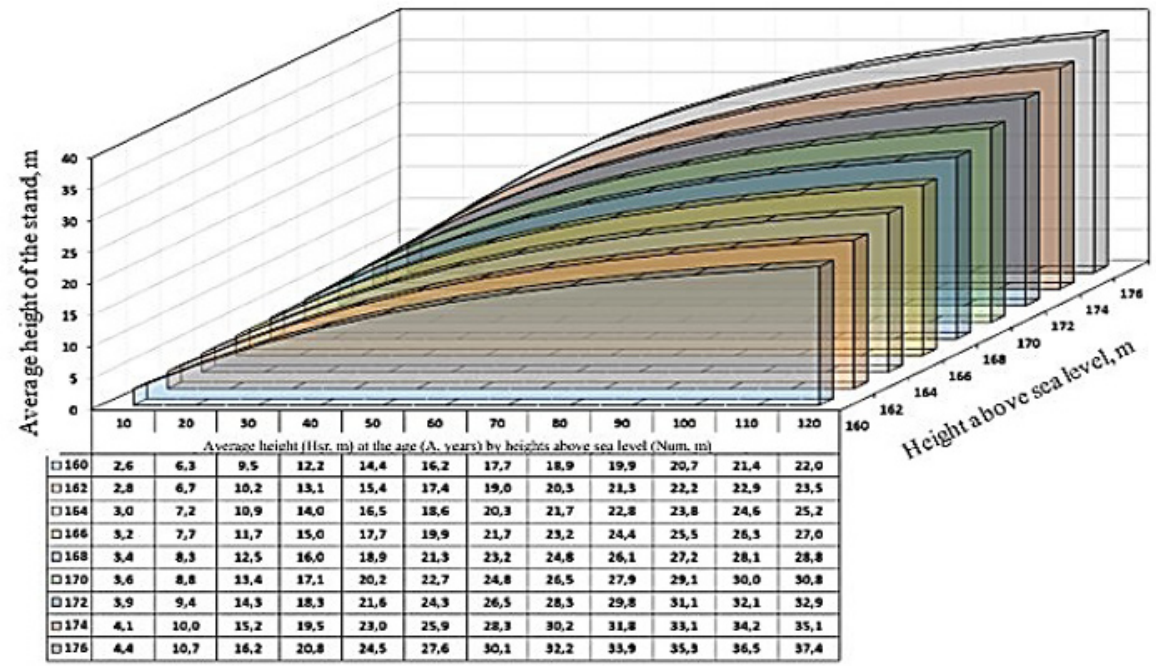

Fig. 3. Age-related change in the average heights of forest stands growing at different heights of the geomorphological profile of the FES.

The regression surface, supplemented by arrows indicating the value of the systematic elevation excess, allows judging the level of excess of the average heights of forest stands at different heights above sea level from the lowest $\left(\mathrm{H}_{\text {yM }}=160 \mathrm{~m}\right)$ to the highest $\left(\mathrm{H}_{\mathrm{yM}}=175 \mathrm{~m}\right)$. Thus, the maximum excess is observed in mature stands and is $15 \mathrm{~m}$, which corresponds to four bonitet classes.

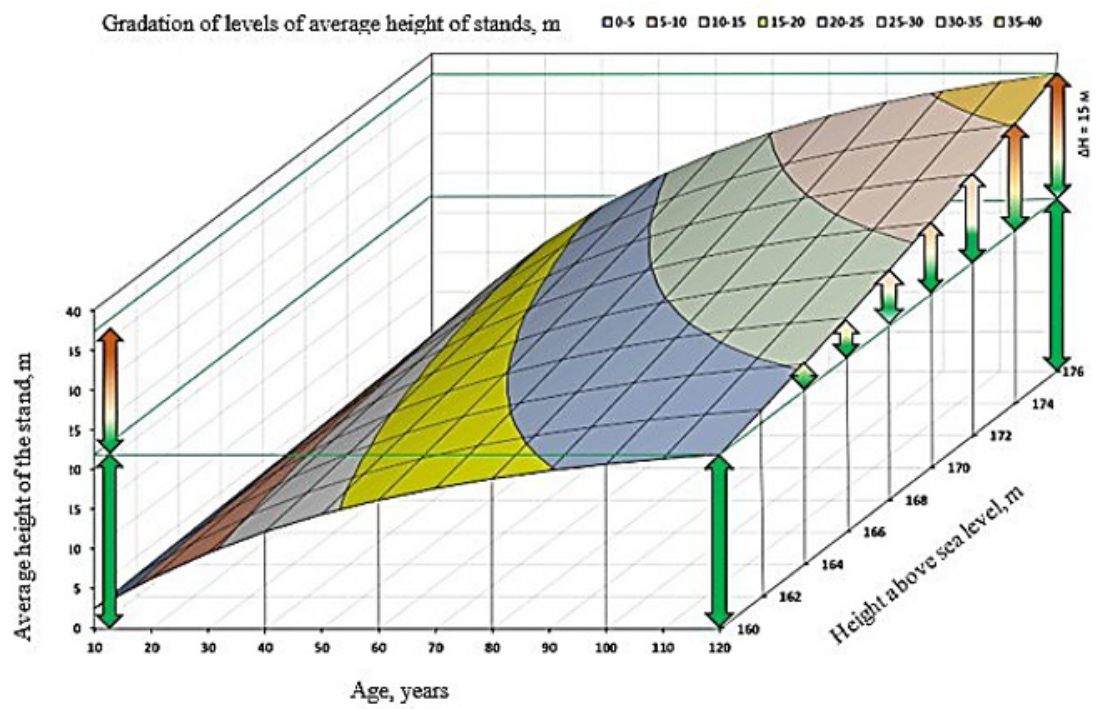

Fig. 4. Graphical representation of the excess of the average height of forest stands at different elevations of the geomorphological profile.

Legend: $\Leftrightarrow$ the top of the moraine hill, $\Leftrightarrow$ the slopes of the moraine hill, $\Leftrightarrow$ the surface of the water-glacial plain, $\Leftrightarrow$ the surface of the valley-like depressions 
All the features of the revealed conformities are clearly visible in the upper part of the figure, bounded by a green outline. The proposed statistical model of average height (2) is the basis for assessing the tree stock and biological productivity of forest elements both with age and in statics with a known completeness and proportion of the species in the composition of the forest stand. So, in accordance with the normative and reference materials for assessing productivity, it is only necessary to calculate the potential reserve of individual elements of the dendrocenosis (tree species), provided that they have formed pure in composition (10 units) and maximally closed forest stands with the completeness taken as 1.0. To do this, it is enough to use the standard tables compiled for forest-forming species, in which the functional relationship of the stock with the average height of the forest stands is presented. So, the stock in 100-year-old pine stands with $\mathrm{H}_{\mathrm{UM}}=160 \mathrm{~m}$ is from 330 to $400 \mathrm{~m}^{3} / \mathrm{ha}$, with $\mathrm{H}$ $\mathrm{UM}=175 \mathrm{~m}$, respectively $730-844 \mathrm{~m}^{3} / \mathrm{ha}$; in larch crops with $\mathrm{H}_{\mathrm{UM}}=160 \mathrm{~m}-350-380 \mathrm{~m}^{3} /$ ha, with $\mathrm{H}_{\mathrm{UM}}=175 \mathrm{~m}-680-770 \mathrm{~m}^{3} /$ ha; in birch stands with $\mathrm{H}_{\mathrm{UM}}=160 \mathrm{~m}-220-240 \mathrm{~m}^{3}$ / ha, with $\mathrm{H}_{\mathrm{UM}}=175 \mathrm{~m}-550 \mathrm{~m}^{3} /$ ha; in oak stands with $\mathrm{H}_{\mathrm{UM}}=160 \mathrm{~m}-300 \mathrm{~m}^{3} /$ ha, with $\mathrm{H}_{\mathrm{UM}}=175 \mathrm{~m}-530 \mathrm{~m}^{3} / \mathrm{ha}$. A decrease in the completeness of forest stands and the share of wood species in the composition of the forest stand directly proportionally reduces the productivity of a particular forest element.

Thus, the demonstrated method of collecting and analyzing data located at different elevations with the corresponding structure of soil geomorphology allows us to come close to identifying the conformities of formation of forest phytocenoses in the context of soil types and soil differences.

\section{Conclusions}

1.The productivity of forest stands is influenced by the location of the stands on the geomorphological profile of the FES territory.

2.In the range of elevations from 160 to $173 \mathrm{~m}$ above sea level, the excess of average heights at the age of mature forest stands (120 years) is $15 \mathrm{~m}$, which corresponds to four bonitet classes.

3.The proposed statistical model of average height is the basis for modeling the course of growth of forest stands both in height and in terms of productivity at a given completeness and proportion of tree species in the composition of forest stands.

\section{Reference}

1. A. R. Vargas de Bedemar, Taxation of the forest dacha of the Petrovsk Agricultural Academy, 281 (1863)

2. D. A. Danilov, V. P. Tsarenko, Izvestia SPbGAU, 38, 76 (2015)

3. Yu. P. Demakov, A. V. Isaev, Eko-Potential, 4(8), 41 (2014)

4. Yu. P. Demakov, A.V. Isaev, N. B. Nureyev, I. I. Mityakova, Bulletin of the Volga State Technological University, 3(39), 30 (2018)

5. N. V. Dylis, V. N. Sukachev, Fundamentals of forest biogeocenology (Nauka, Moscow, 1964), 574

6. B. D. Zaicev, Forest and soil (Publishing house of the forest industry, M., 1964), 159

7. V. D. Zelikov, Soil and quality of plantings (Timber Industry, 1971), 120

8. S. V. Zonn, The influence of the forest on the soil (Publishing house of the Academy of Sciences, M., 1954), 160

9. L. O. Karpachevsky, Forest and forest soils (Lesnaya promyshlennost, M., 1981), 264 
10. L. O. Karpachevsky, The diversity of the soil cover in the forest biogeocenosis (Moscow State University Publishing House, Moscow, 1977), 312

11. O. V. Martynenko, Influence of soil factors on the growth and productivity of pine plantations on the example of SCHUOLH of the Moscow region (Moscow, 2011), 135

12. M. D. Merzlenko, P. G. Melnik, G. N. Vysotsky, Sustainable forest management, 44 (2015)

13. N. P. Remezov, P. S. Pogrebnyak, Forest soil science (Publishing House of the Forest Industry, 1965), 323

14. V. K. Khlyustov, Comprehensive assessment and management of wood resources: models-standards-technologies $<$ Book I $>$ (Publishing house of the Russian State Agricultural University named after K.A. Timiryazeva, M., 2015), 389

15. V. K. Khlyustov, Comprehensive assessment and management of wood resources: models - standards - technologies $<$ Book II $>$ (Publishing house of the Russian State Agricultural University named after K.A. Timiryazeva, M., 2015), 449

16. A. I. Aristarkhov, Optimization of plant nutrition and the use of fertilizers in agroecosystems (TsINAO, M., 2000), 520

17. N. V. Voitovich, Soil fertility of the Non-Chernozem zone and its modeling (Kolos, M., 1997), 387

18. A. G. Zamaraev, V. I. Savich, V. G. Sychev, Energy and mass exchange in the link of field crop rotation, part 2 (VNIIA, M., 2005), 336

19. V. I. Savich, V. A. Sedykh, S. A. Izmailova, Agrochemical Bulletin, 4, 21 (2012)

20. V. I. Savich, O. D. Sidorenko, L. V. Mosina, J. Norovsuren, D. S. Anikina, Int. agricultural zh-1, 1, 32 (2019)

21. V. I. Savich, S. P. Torshin, S. L. Belopukhov, V. A. Sedykh, Agroecological assessment of organo-mineral complex compounds of soils (OOO Megaprint, Irkutsk, 2017), 298

22. K. M. Tuğrul, Soil Management in Sustainable Agriculture, Sustainable Crop Production, Mirza Ha-sanuzzaman, Marcelo Carvalho Minhoto Teixeira Filho, Masayuki Fujita and Thiago Assis Rodrigues Nogueira, IntechOpen (2019)

23. J. D. Phillips, Soil Complexity and Pedogenesis. Soil Science, 182(4), 117 (2017)

24. P. Lavelle; A. Spain; M. Blouin; G. Brown; T. Decaëns; M. Grimaldi; J. J. Jiménez; D. McKey; J. Mathieu; E. Velasquez; A. Zangerlé, A Review of Concepts and Future Research Questions. Soil Science, 181(3/4), 91 (2016)

25. J. Shengyao, Y. Xianglong, Z. Jianming, L. Guang, Soil Science, 179(4), 211 (2014)

26. F. Nicholson, A. Bhogal, M. Taylor and et al., Soil Science, 183(3), 89 (2018)

27. W. Dong, X. Zhang, H. Wang and et al., Effect of Different Fertilizer Application on the Soil Fertility of Paddy Soils in Red Soil Region of Southern China (2012)

28. W. Jr. Shepherd, P. Liang, X. Jiang, M.P. Doyle, M.C. Erickson, Microbiological analysis of composts produced on South Carolina poultry farms (2011) 